\title{
Fundamental Factor Analysis on Stock Returns Based on the Panel Data of LQ'45 Index
}

\author{
Sumania,* \\ ${ }^{a}$ Faculty of Economics and Business, University of Jember, Jember
}

\begin{abstract}
This study aims to investigate the influence of fundamental factors on stock returns on the companies listed in the LQ'45 index in the Indonesia Stock Exchange. This research uses explanatory research design. The population consists of 45 companies listed in the LQ'45 index. The purposive sampling technique is used and collected a total of 23 companies as the sample. The number of samples was 23 companies because these companies consistently formed the LQ'45 index for the 2014-2018 periods. Those companies are fulfilling the criteria which are continually included in the LQ' 45 index throughout the analysis period. Thus, the data panels used in this study were as much as 115 observations. Fundamental factors proxied by TATO, MBV, CR, DER, NPM, and EPS. The multiple linear regression analysis is used and the results showed that TATO has a significant positive effect on stock returns, MBV has a significant negative effect on stock returns, while CR, DER, NPM, and EPS have no significant effects on the stock return of LQ'45 index-listed companies.
\end{abstract}

Keywords: fundamental, stock returns, LQ-45, Indonesian stock exchange

\section{INTRODUCTION}

Investors mostly invest in certain shares that many other investors are interested in. One index demanded by most of the investors before they decide to invest and used as the reference is the LQ'45 index. LQ'45 index is an index composed of 45 companies that have a large market capitalization level, have good financial fundamentals condition, and are the best choice of shares in the Indonesia Stock Exchange (IDX). This made LQ'45 index forming companies were always in demand by investors over the years as a place to invest in shares.

Investor interest, based on the LQ'45 index movement observed from the beginning of 2014 until the end of 2018, has a rising trend both on the average price of shares and the trading volume of shares traded.

Furthermore, based on data obtained from kontan.co.id, indicating that the LQ' 45 index in 2014 has a return of $22.33 \%$ which is higher than the increase in the Indonesia Composite Index (ICI) of $18.65 \%$, although the previous performance of LQ'45 index is minus by $3.35 \%$. Throughout 2017 , LQ' 45 index performance regained the lead against ICI which LQ' 45 index grew by $22.02 \%$ while the ICI grew by $19.99 \%$. The growth

\footnotetext{
*Author in correspondence,

Email address: sumanisumani69@gmail .com (Sumani)
}

ISSN: 2549-3221 (Print) 2549-323X (Online)

DOI: $10.26487 /$ hebr.v3i3.2195 of LQ'45 index performance throughout 2017 was marked by the rise of stock price of several companies that forming the index such as PT Bank Tabungan Negara (BBTN) that recorded the highest increase of $105.17 \%$ to Rp 3,570 per share, PT Bank Negara Indonesia Tbk (BBNI) of 79.19\% to Rp 9,900 per share, PT Bank Central Asia Tbk (BBCA) of 41.29\% to Rp 21,900 per share, PT Barito Pacific Tbk (BRPT) of 54.27\% to Rp 2,260 per share, and PT Jasa Marga Tbk (JSMR) of $48.15 \%$ to Rp 6,400 per share.

According to the data obtained from Cnbcindonesia (2018), showed that global economic conditions influenced the policy adopted by The Fed to raise interest rates four times, resulting in the rupiah weakened to the level of Rp 15,256 per USD. This situation causes the LQ'45 index to weaken. However, based on the data obtained from market.bisnis.com, stated that performance of LQ' 45 index at the end of 2018 began to improve, it characterized by the improvement in various industry sectors, infrastructure, and consumer goods, plus the performance of some listed companies are starting to improve as TLKM, PGAS, ITMG, INTP, and SMGR. Based on the phenomenon, it indicates that investors are increasingly interested in and trust to invest in shares of LQ'45 index forming companies.

Investation is the investment activities undertaken by investors to gain an advantage in the future. According to Jogiyanto (2017) investment is a delay of current consumption employing allocating it into productive assets within a certain time-frame. 
Gains or losses earned by investors from the stock-purchase is usually called the gain/loss, while the share price change is called the stock return.

Stock return is the rate of return on investment in the form of shares. In principle, the higher the profit of the stock desired by investors, the greater the risk that will be accepted. With a high level of risk and fluctuating stock returns on the stock exchange, investors must be able to predict both the selection of companies to buy shares and stock price movements to avoid losses. There are various ways to analyze stock returns that can be used by investors including fundamental analysis.

According to S. (2013), corporate fundamentals are circumstances that are directly related to company performance. It can be concluded that the fundamental analysis of the company is done by finding actual data that is directly related to the performance of each issuer.

Because basically, the word fundamental means "basic" or "main" of something that can be used as reference material, such as investors and stakeholders who need financial reports as a source of their information on company performance. According to William et al. (1999), analysis of financial statements is one of the fundamental analyses that are used and studied by analysts to predict the future consisting of ratio analysis. According to Margaretha (2014), there are 5 types of ratios that are commonly used including Liquidity Ratio, Asset Management Ratio, Debt Management Ratio, Profitability Ratio, and Market Value Ratio.

Research on the capital market has been carried out, especially regarding the fundamental factors of companies that affect stock returns, such as research on the influence of the Current Ratio (CR) variable on stock returns conducted by Prihantini (2009) stating that CR has a significant positive effect on stock returns. While research conducted by Susanty (2018) states that CR does not have a significant negative effect on stock returns.

Furthermore, several studies on the influence of Total Assets Turnover (TATO) on stock returns as Saniman (2007) states that TATO has a significant positive effect on stock returns. While the research conducted by Prihantini (2009) found that TATO has a significant negative effect on stock returns.

Then, the research on the effect of Debt to Equity Ratio (DER) conducted by Prihantini (2009) states that the DER has a significant negative effect on stock returns. Followed by research on the influence of Net Profit Margin (NPM) conducted by Ozturk and Karabulut (2018), states that NPM has a significant effect on stock returns. While research conducted by Susilowati (2011) states that NPM has no significant effect on stock returns.

Inconsistent research results are also still found in research on the effect of variable Earning Per Share (EPS) on stock returns conducted by Gunadi and Kesuma (2015) and Muhammad and Ali (2018), which states that EPS has a significant positive effect on stock returns. While research conducted by Arista and Astohar (2012) states that EPS has no significant effect on stock returns.

Similarly, research on the effect of Market to Book Value (MBV) conducted by Arista and Astohar (2012) states that MBV has a significant positive effect on stock returns. The results of some of the studies above show the existence of gap research, this is interesting to do further research on companies that are included in the LQ'45 index.

The purpose of this research is to: (1) analyze the influence of CR on stock return of the LQ'45 index forming company; (2) analyze the influence of TATO on stock return of the LQ'45 index forming company; (3) analyze the effect of DER on stock return of the LQ'45 index forming company; (4) analyze the effect NPM on stock return of the LQ'45 index forming company; (5) analyze the effect of EPS on stock return of the LQ'45 index forming company; (6) analyze the effect MBV on stock return of the LQ'45 index forming company, listed in IDX.

\section{RESEARCH METHOD AND DESIGN}

The research design used is explanatory research that is research that aims to show the position of the variables studied and the influence of one variable to another variable (Sujarweni, 2014). This type of explanatory research is used to test the fundamental factors that are proxied by independent variables (CR, TATO, DER, NPM, EPS, and MBV) on stock returns of companies included in the LQ'45 Index.

The researcher uses secondary data, which is obtained using documentation, that is, the researcher collects data in the form of the company's annual financial statements listed on the IDX and as forming the LQ' 45 index for the $2014-2018$ period. The data source of this research came from the official site of the IDX (www.idx.co.id) as well as the company's official website which was included as an object of research.

The population of this study is companies listed on the IDX that are included in the LQ' 45 index. The sampling technique used is purposive sampling, which is a sampling method based on certain criteria following the needs and objectives of the study. The number of samples was 23 companies because these companies consistently formed the LQ'45 index for the 20142018 period. Thus, the data panels used in this study were as much as 115 observations.

\subsection{Data analysis method}

The analytical method used is multiple linear regression method. The value of each variable is determined by the formula including:

\section{- Current Ratio (CR)}

According to Prihantini (2009), the Current Ratio (CR) is one measurement of the company's liquidity to determine a company's ability to repay short-term liabilities with current assets owned. This ratio is measured by the formula:

CR : (Current Assets)/(Current Liabilities)

\section{- Total Assets Turnover (TATO)}

Total Assets Turnover (TATO) is a ratio used to measure the rate of return on assets of the company in a single year (Moeljadi: 2006). This ratio is measured by the formula:

TATO : Sales/(Total Assets) 
- Debt to Equity Ratio (DER)

Debt to Equity Ratio (DER) is the ratio used to measure how well the company meets all its obligations with its capital (Moeljadi: 2006). This ratio is measured by the formula:

DER : (Total Liabilities)/Equity

- Net Profit Margin (NPM)

According to Moeljadi (2006) NPM demonstrates the ability to generate any net sales. This ratio is measured by the formula:

NPM : (Net Profit)/(Sales )

- Earning Per Share (EPS)

According to Fahmi (2015) Earning Per Share (EPS) is earnings per share as the form of the advantage given to the shareholders of each share owned. This ratio is measured by the formula:

EPS : (Net Profit)/(Number of Shares Outstanding)

- Market to Book Value (MBV)

According to Arista and Astohar (2012) Market to Book Value (MBV) is a ratio to measure the movement of stock price to its book value. According to Susanty dan Bastian (2018) if the MBV ratio is higher, then it shows that the stock price in the market is higher than its intrinsic value so that capital gains or profits will be higher. To calculate this ratio, it is necessary to calculate book value per share (BVS) beforehand. The formula to calculate BVS are:

BVS : (Total Equity)/(Number of Shares Outstanding)

thus, the formula for calculating the MBV is:

MBV : (Price per Shares)/(Book Value per Shares)

\section{- Stock Return}

Stock return is the change in the price of a stock investment. Stock returns can be positive or negative, which means that if the return is positive, the price increases from the previous period, while negative returns mean a decline in prices from the previous period (OK.com shares). According to Jogiyanto (2017) returns can be divided into two:

(a) return realization is the return that has been the stock market, and

(b) the expected return is return desired by investors.

The type of return used in this study is the return realization, in which returns have occurred in the market for company stocks that included in the LQ'45 Index. The formula for calculating stock returns is:

Stock return realization : $P_{t}-P_{t-1}+D_{t} / P_{t-1}$

Note:

$P_{t}$ : The price of the company's shares on period $\mathrm{t}$

$P_{t-1}:$ The price of the company's shares on period t-1 dt : Dividends paid by companies per share(cash dividend).

Multiple linear regression model equation as follows:

$Y: \alpha+\beta_{1} C R+\beta_{2} T A T O+\beta_{3} 3 D E R+\beta_{4} N P M+\beta_{5} E P S+$ $\beta_{6} M B V+\epsilon$

Note :

$\mathrm{Y}:$ stock return

$\alpha:$ constant

$\beta$ : regression coefficients

$\mathrm{CR}$ : current ratio

TATO : Total Assets Turnover

DER : Debt to Equity Ratio

NPM : Net Profit Margin

EPS : Earning Per Share

MBV : Market to Book Value

$\mu$ : error

\subsection{Test of Classic Basic Assumptions}

The classic basic assumption test is an analysis to find out whether in a linear regression model there is a classic assumption problem. For the model to be used as a predictor, the model must meet the BLUE (Best Linear Unlimited Estimator) criteria, so a classic assumption test (multicollinearity, autocorrelation, and heteroscedasticity) needs to be done.

\section{FINDINGS AND ANALYSIS}

\subsection{Normality Test Data}

This data normality test is carried out to find out whether the research data is normally distributed or not. Testing the normality of this data using the Kolmogorov-Smirnov test with a decision if the significance value of Kolmogorov-Smirnovi 0.05 then the data is normally distributed, and if the data 0.05 then the research data is not normally distributed.

Table 1: Results of Kolmogorov-Smirnov test

\begin{tabular}{ll}
\hline Research variable & Asymp. Sig. (2-tailed) \\
\hline CR & .0000 \\
TATO & .0000 \\
DER & .0000 \\
NPM & .0000 \\
EPS & .0000 \\
MBV & .0000 \\
RETURN & .0000 \\
\hline
\end{tabular}

Source: (data processing)

Based on the Kolmogorov-Smirnov test results above, it can be stated that all data in the study variable are not normally distributed due to all Asymp values. Sig. (2-tailed) is smaller than 0.05 . Because all data is not normally distributed, a semivariable $\log (\mathrm{Ln})$ data transformation is done.

Based on the results of the Kolmogorov-Smirnov Semi Log (Ln) Transformation Variable Dependent above, it can be stated 
Table 2: Results of the Kolmogorov-Smirnov Test Transformation Semi log (Ln) Dependent Variables

\begin{tabular}{ll}
\hline Research variable & Asymp. Sig. (2-tailed) \\
\hline CR & .000 \\
TATTOOS & .000 \\
DER & .000 \\
NPM & .000 \\
EPS & .000 \\
MBV & .000 \\
Ln_RETURN & 0.196 \\
\hline
\end{tabular}

Source: (data processing)

Table 3: Results of the Kolmogorov-Smirnov Test Transformation Semi $\log (\mathrm{Ln})$ Independent Variables

\begin{tabular}{|c|c|c|}
\hline $\begin{array}{l}\text { Research } \\
\text { able }\end{array}$ & vari- & Asymp. Sig. (2-tailed) \\
\hline \multicolumn{3}{|l|}{ Ln_CR } \\
\hline Ln_TATO & & .000 \\
\hline Ln_DER & & .000 \\
\hline \multicolumn{3}{|l|}{ Ln_NPM } \\
\hline \multicolumn{3}{|l|}{ Ln_EPS } \\
\hline Ln_MBV & & .000 \\
\hline RETURN & & .000 \\
\hline
\end{tabular}

Source:data processing

that only the dependent variable is normally distributed due to Asymp. Sig. (2-tailed) is greater than 0.05. While the CR, TATO, DER, NPM, EPS, and MBV variables are not normally distributed because of Asymp. Sig. (2-tailed) is smaller than 0.05 . Because the results still show that most data are not normally distributed, semi-independent $\log (\mathrm{Ln})$ data transformation is performed.

Based on the results of the Kolmogorov-Smirnov Semi Log (Ln) Transformation Independent Variables above, it can be stated that only EPS variables are normally distributed due to Asymp. Sig. (2-tailed) is greater than 0.05. While the CR, TATO, DER, NPM, MBV, and RETURN variables are not normally distributed because of Asymp. Sig. (2-tailed) is smaller than 0.05. Because the results still show that most data are not normally distributed, a double $\log (\mathrm{Ln})$ data transformation is performed, in which the independent and dependent variables are converted into the $\mathrm{Ln}$ form.

Based on the Kolmogorov-Smirnov Double Log Transformation (Ln) test results above, it can be stated that only EPS and RETURN variables are normally distributed due to Asymp. Sig. (2-tailed) is greater than 0.05. While the CR, TATO, DER, NPM, and MBV variables are not normally distributed because of Asymp. Sig. (2-tailed) is smaller than 0.05. Because the results still show that most data are not normally distributed using the Ln transformation, another data transformation is done, namely Log10.

Based on the results of the Kolmogorov-Smirnov Log10 Transformation test above, it shows the same results as the dou-
Table 4: Results of the Kolmogorov-Smirnov Test Double Transformation Log (Ln)

\begin{tabular}{ll}
\hline Research variable & Asymp. Sig. (2-tailed) \\
\hline Ln_CR & .005 \\
Ln_TATO & .000 \\
Ln_DER & .000 \\
Ln_NPM & .024 \\
Ln_EPS & $.200, \mathrm{~d}$ \\
Ln_MBV & .000 \\
Ln_RETURN & .196
\end{tabular}

Source:data processing

Table 5: Results of the Kolmogorov-Smirnov Test Transformation Log 10 Research vari- Asymp. Sig. (2-tailed) able

\begin{tabular}{ll}
\hline LOG_CR & .005 \\
LOG_TATO & .000 \\
LOG_DER & .000 \\
LOG_NPM & .024 \\
LOG_EPS & $.200, \mathrm{~d}$ \\
LOG_MBV & .000 \\
LOG_RETURN & .196 \\
\hline
\end{tabular}

Source: data processing

ble Log (Ln) transformation that only EPS and RETURN variables are normally distributed due to Asymp. Sig. (2-tailed) is greater than 0.05. While the CR, TATO, DER, NPM, and MBV variables are not normally distributed because of Asymp. Sig. (2-tailed) is smaller than 0.05 .

Because the results still show that most of the data are not normally distributed using the Log10 transformation, another data transformation is done, namely Square transformation.

\begin{tabular}{ll} 
Table 6: Results of the Kolmogorov-Smirnov Test Transformation Squa \\
\hline Research variable & Asymp. Sig. (2-tailed) \\
\hline SQRT_CR & .000 \\
SQRT_TATO & .043 \\
SQRT_DER & .000 \\
SQRT_NPM & .002 \\
SQRT_EPS & .002 \\
SQRT_MBV & .000 \\
SQRT_RETURN & .200 \\
\hline \multicolumn{2}{l}{ Source: data processing }
\end{tabular}

Based on the Kolmogorov-smirnov Square Transformation test results above, it shows that only one variable, namely RETURN, is able to have a normal distribution due to Asymp. Sig. (2-tailed) is greater than 0.05. While the CR, TATO, DER, NPM, EPS and MBV variables are not normally distributed because of Asymp. Sig. (2-tailed) is smaller than 0.05. Because the results still show that most of the data are distributed abnor- 
mally by using Square transformation, the final data transformation step is done by removing the outlier which is likely to make the research data abnormal.

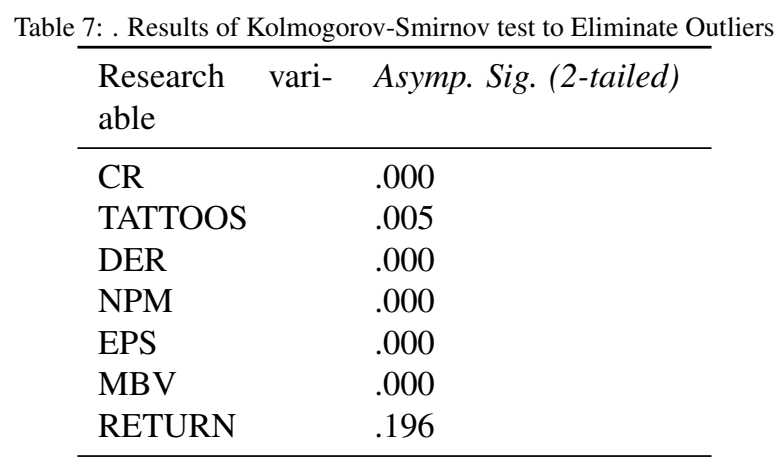

Source: data processing

Based on the Kolmogorov-Smirnov test results by eliminating the outliers above, it shows that only one variable, namely RETURN, is able to have a normal distribution due to Asymp. Sig. (2-tailed) is greater than 0.05. While the CR, TATO, DER, NPM, EPS and MBV variables are not normally distributed because of Asymp. Sig. (2-tailed) is smaller than 0.05. Because after being tested using the latest method and still showing most of the data are not normally distributed, the authors quote the Central Limit Theory from a book written by Dinov et al., (2008) which states that the majority of statisticians consider the research data sample 30 or more is big enough to apply the middle limit theory. This middle limit theory explains that if a study has at least 30 or more data, then the data is assumed to be normally distributed.

\subsection{Multiple Linear Regression Analysis}

Based on the results of multiple regression analysis above, then obtained a regression model as follows:

$Y:-409.942+-0,038 C R+0,191 T A T O+0,023 D E R+$ $0,577 N P M+3,572 E P S+-0,005 M B V+\epsilon$

\subsection{MulticollinearityTest}

This multicollinearity test was conducted to determine whether there is a correlation between the independent variables in the multiple linear regression model. To determine the occurrence of multicollinearity, this test uses Tolerance and Variance Inflation Factor (VIF) values. If the Tolerance value $>0.01$ and VIF value $<10$, the model is free from multicollinearity, and vice versa.

The multicollinearity test results above indicate that the multiple linear regression model is free from the presence of multicollinearity, that is, there is no correlation between the independent variables.

\subsection{Heteroscedasticity test}

This heteroscedasticity test was conducted to find out whether the multiple linear regression model experienced heteroscedasticity problems. This test uses a glacier test by way of re-
Table 8: Test Results Multicollinearity

\begin{tabular}{lcc}
\hline $\begin{array}{l}\text { Independent } \\
\text { variables }\end{array}$ & Tolerance & $\begin{array}{l}\text { Variance Inflation } \\
\text { Factor (VIF) }\end{array}$ \\
\hline CR & 0.758 & 1,319 \\
TATTOOS & 0.25 & 3,997 \\
DER & 0.454 & 2,201 \\
NPM & 0.693 & 1,443 \\
EPS & 0.816 & 1.225 \\
MBV & 0.376 & 2,657 \\
\hline
\end{tabular}

Source: data processing

gressing the value of the independent variable with the residual value. If the significance value generated from the heteroscedasticity test $; 0.05$ then the regression model does not experience heteroscedasticity problems and vice versa.

Based on the results of heteroscedasticity test above shows that all independent variables in this study did not experience heteroscedasticity problems.

\subsection{Autocorrelation test}

Table 9: Test Results autocorrelation

\begin{tabular}{ccccc}
\hline DW & dL & dU & 4-dL & 4-dU \\
\hline 2.046 & 1.5691 & 1.8265 & 2.4309 & 2.1735 \\
\hline
\end{tabular}

Source: data processing

This autocorrelation test was conducted to determine the correlation between the residuals of one observation and the other observations in the multiple linear regression model.

These results state that negative autocorrelation occurs in multiple linear regression models according to the basis of the decision if 4-dL dw 4, then negative autocorrelation occurs. This is proven because the results show that 2,4309 2,697 4 . Because of negative autocorrelation, improvements were made using the Chocrane-Orcutt method.

Table 10: Test Results autocorrelation with Chocrane-Orcutt method
\begin{tabular}{cccccc} 
DW & dL & Du & 4-dL & 4-dU \\
\hline 2.697 & 1.5691 & 1.8265 & 2.4309 & 2.1735 \\
\hline
\end{tabular}

Source: data processing

These results state that the model is free from negative autocorrelation problems with the basis of the decision if $\mathrm{dU} d w$ 4-dU, then there is no positive or negative autocorrelation. This is proven by $1.82652,0462.1735$. With this result, the previous multiple linear regression model changes to multiple linear regression with the Lag model, because the model that has been transformed has been freed from all existing classical assumptions. Improvements to the autocorrelation that have been done produce a new multiple linear regression model equation, obtained a new regression model as follows: 
$\operatorname{Lag} Y:-1,583.280+-0,038 \operatorname{LagCR}+0,036 \operatorname{Lag} D E R$ $+0,273 \operatorname{Lag} T A T O+-0,008 \operatorname{Lag} M B V+1,416 \operatorname{Lag} E P S+$ $0,592 \operatorname{LagNPM}+\mu$

\subsection{Hypothesis testing}

Hypothesis testing in this study was conducted using $\mathrm{t}$ test. $\mathrm{T}$ test is done to find out how much the independent variable is able to partially influence the dependent variable.

Based on the results of the $t$ test above, it shows that Total Assets Turnover (TATO) has a significant positive effect on stock returns. Market to Book Value (MBV) variable has a significant negative effect on stock returns. While the Current Ratio (CR), Debt to Equity Ratio (DER), Net Profit Margin (NPM), and Earning Per Share (EPS) variables have no significant effect on stock returns.

Based on the results of the t-test above, it shows that Total Assets Turnover (TATO) has a significant positive effect on stock returns. Market to Book Value (MBV) variable has a significant negative effect on stock returns. While the Current Ratio (CR), Debt to Equity Ratio (DER), Net Profit Margin (NPM), and Earning Per Share (EPS) variables have no significant effect on stock returns.

\section{DISCUSSION}

Based on the hypothesis testing results, Current Ratio (CR) has no significant effect on stock returns, which means that any changes made to the current ratio, either increase or decrease, do not have a significant impact on stock returns. It states that the CR data from the 2014-2018 period do not have sufficient ability to predict the movement of stock returns forming the LQ'45 index in Indonesia Stock Exchange (IDX). CR movement that is not in line with the fluctuations of stock returns forming the LQ' 45 index indicates that any enhancement of CR will not affect stock return volatility of the LQ'45 index forming company in IDX.

This may happen because the investors do not consider CR as the only consideration for their investment decisions. Because, although the LQ'45 index forming companies have a good CR level, they have not been able to raise the interest of investors to buy the company's stock. The investors in Indonesia, especially those who are very ordinary regarding the company's financial reports, tend to ignore the fundamental factors of the company and more into using the technical analysis. Technical analysis is considered to be more convenient for most investors in Indonesia because they simply want a quick profit from the stock purchase without consideration for the long-term gains. On the other hand, technical analysis is more easily to be understood by many people and quicker to serve as consideration for investment decision rather than a fundamental analysis that requires more time to analyze. The results of this study are consistent with the results of research conducted by Susanty (2018) which states that $\mathrm{CR}$ has no significant negative effect on stock returns. However, it does not support the research of Khotimah and Murtaqi (2015), Muhammad and Ali (2018), Bintara and Tanjung (2019).
Total Assets Turnover(TATO) has a significant positive effect on stock returns, which means that any changes to the increase in total assets turnover will affect stock returns positively. Similarly, if the ratio of total asset turnover in companies that consistently forming the LQ'45 index decreased, then stock returns will also be decreased. Total asset turnover is the ratio that measures how well companies utilize their assets to generate sales. The higher this ratio, the more effective the company is in managing its assets to gain net sales.

Net sales are one indicator that is seen by investors as investors assess that the higher sales generated by the company, the greater the advantage to be gained by the company. Therefore, the higher this ratio, the higher the stock returns, the higher the value-added, and the higher the investor's confidence. The results of this study are consistent with the results of research conducted by Saniman (2007), Fredrick and Muiva (2015) and Khotimah and Murtaqi (2015) which states that the TATO has a significant positive effect on stock returns.

Debt to Equity Ratio (DER) has no significant effect on stock returns, which means that any change in DER, either increase or decrease, does not have a significant impact on stock returns. This proves the explanation that says it is not always high DER companies will also highly indicated to have poor performance. It reinforced by the data of all banking companies in the research (PT Bank Central Asia Tbk, PT Bank Negara Indonesia Tbk, PT Bank Rakyat Indonesia Tbk, and PT Bank Mandiri Tbk) that have high levels of DER. The high value of DER at the banking companies are reputed to be reasonable, given the role of banking companies are only to distribute money from customers and then lent it to people in need of capital. All funds raised from the customers, in the form of savings, checking, and etc, are debt, that then used to lend to other customers. It means banks are not able to operate properly in the absence of loans from clients and others.

As well as other companies that require large debt as additional capital for the company, especially if it is a large company. This makes investors do not always trust the companies's and in fact, the level of stock price changes in the banking sector is much more stable compared to other sectors.

Moreover, if the company, either bank or non-bank, is capable to incorporate as LQ'45 index forming companies in IDX, that consisted of leading shares and have prospects for good company performance. The results of this study are consistent with research conducted by Suselo et al. (2015) which states that the DER has no significant effect on stock returns. The study supported Fredrick and Muiva (2015) but did not support the research of Muhammad and Ali (2018), Bintara and Tanjung (2019).

Net Profit Margin(NPM) has no significant effect on stock returns, which means that any changes in the NPM, either increase or decrease, do not have a significant impact on stock returns. This can be explained because it is not always the higher net income in the company that is able to describe the state of fluctuations in stock returns in the stock market. Even though the theory says if the net profit increases, the value of the company will also increase, and investors trust the company's performance. This can be shown by one example of a company 


\begin{tabular}{lcccc}
\multicolumn{5}{c}{ Table 11: Test Results } \\
$\begin{array}{l}\text { Var. Indepen- } \\
\text { dent }\end{array}$ & Coefficient & t. count & t. Table & Sig. \\
\hline constants & & & & \\
LagCR & $-1,583.28$ & -0.893 & & 0.374 \\
LagTATO & -0.038 & -1.684 & 1.98217 & 0.095 \\
LagDER & 0.273 & 2.458 & 1.98217 & 0.016 \\
LagNPM & 0.036 & 1.625 & 1.98217 & 0.107 \\
LagEPS & 0.592 & 1,781 & 1.98217 & 0.078 \\
LagMBV & $1.42 \mathrm{E}-02$ & 0.341 & 1.98217 & 0.734 \\
\hline
\end{tabular}

Source: data processing

in the research, PT. Bukit Asam Tbk (PTBA). PTBA in 2014 recorded a net profit of $\mathrm{Rp} 2,019,214,000,000$ while in 2015 recorded a net profit of $\mathrm{Rp} 2,024,405,000,000$, which means there is an increase in net profit of Rp 5.191 billion. Nevertheless, PTBA stock prices in 2014 and 2015 decreased dramatically from $\mathrm{Rp} 2,500$ to $\mathrm{Rp} 905$ per share. This proves that it is not enough if investors judge the movement of the stock return solely based on its net income in financial statements because the stock market is so dynamic and also possible to be affected by global economic issues as well as events that occurred. For instance, is JCI performance decline in 2015 due to the weakness of the rupiah against the USD weakened people's purchasing power, and this event resulted in 285 of the 339 shares of the company fell to make JCI in the red zone Afriyadi (2015), however, it does not support the research of Allen et al. (2017), and Muhammad and Ali (2018).

On the other hand, the larger the company will increasingly possible for the company to conduct earnings management practices. According to Agustia and Suryani (2018), earnings management is managers' attempt to intervene or influence the information of the company's earnings in particular on the financial statements to deceive financial performance.

It has become a common thing as marked by numerous financial research, especially on the topic of earnings management. Earnings management itself is done by making information about the company's profit as attractive as possible so that investors are interested to invest in stocks in a company and so that the company is increasingly trusted for its performance. But investors today are getting smarter and not solely looking at the company's high profits anymore, as investors are more interested in a definite advantage gained rather than just look at the numbers in net profit on the company's financial statements. Savvy investors tend to utilize every means possible and every information he received, to not only make investment decisions in buying stocks based information on net profit and a long period it retained. Because the condition of the stock market is also sensitive to the issues that are owned by a company that has an impact on the confidence of investors to buy stocks, as well as the existing global economic issues. The results of this study are consistent with research conducted by Susilowati (2011) which states that the NPM has no significant effect on stock returns.
Earning Per Share(EPS) has no significant effect on stock returns, which means that any changes in the EPS, either increase or decrease, do not have a significant impact on stock returns. The EPS is the ratio that describes how much the company can produce earnings per share outstanding in the capital market. The theory says that the greater the EPS or EPS to be distributed then the value of the company will increase in the eyes of investors, with the hope of the prospects of the company will be better so that the stock price will be more expensive. But the theory did not reflect the actual situation of the present capital market forever. This theory does not apply where a company has experienced operational problems that create a negative issue for shareholders and investors and its shareholders later choose to switch to buy other stocks. One example is PT Lippo Karawaci Tbk (LPKR) that projected EPS in 2017 amounted to Rp. 37.13, and then in 2018 amounted to Rp 74.79.

But this is not followed by the constraints experienced by the LPKR who had to be trending in mid-2018 with suspicion of bribery case against the Bekasi Regent on Meikarta project development(Houtman, 2018). This makes stock returns of LPKR decline from -0.3196 in 2017 and to -0.4740 at the end of 2018 . This negative sentiment is making investors lost their interest over LPKR shares, makes it less enjoyable. Less enthusiastic over the LPKR's stock makes its stock prices decreased. Therefore, investors are not always looked at the ratio of EPS as a source of decisions in investing because of many factors to be considered by investors before buying a company's stock. The results of this study are consistent with research conducted by Susilowati (2011) and Arista and Astohar (2012) which states that the EPS effect is not significant to stock return. But does not support research on Bintara and Tanjung (2019).

Market to Book Value (MBV) has a significant negative effect on stock returns, which means that any gains in the MBV will lower stock returns. The theory says if the ratio of MBV increased or exceed the number of 1 , it means that the stock price outstanding is more expensive than its intrinsic price so that the possibility of Capital Gains received will be greater. But in this study, the increase of MBV would lower stock returns, which means that the more expensive the stocks of the LQ'45 index forming company in IDX, it decreases the stock returns. This indicates that investors still consider the MBV as 
of their consideration to investing in stocks of the LQ'45 index forming company in IDX. The stock price in the market is too much more expensive than its intrinsic price, it makes investors rethink whether buying the expensive stock will always worth the benefit. This coupled with the trend of the rising value of the USD over the Rupiah that resulted in the decreasing tendency of index movement due to the decreasing interest of investors to buy stocks. The results of this study supported the research of Khotimah and Murtaqi (2015), Muhammad and Ali (2018) but did not support the research of Venkates et al. (2012), Bintara and Tanjung (2019).

\section{CONCLUSION}

Fundamental factors proxied by the Current Ratio (CR), Net Profit Margin (NPM), Earning Per Share (EPS), and Debt to Equity Ratio (DER) partially are not indicated to have a significant effect on stock returns on LQ'45 index-listed companies. Fundamental factors proxied by Total Assets Turnover (TATO) are indicated to have a significant positive effect on stock returns on LQ'45 index-listed companies. Fundamental factors proxied by Market to Book Value (MBV) are indicated to have a significant negative effect on stock returns on LQ' 45 indexlisted companies.

\section{References}

Afriyadi, A. D., Jun 2015. Ihsg sulit tembus level 5.000 pada akhir 2015. Media Online. 25.

URL: https://www.liputan6.com/bisnis/read/2300522/ ihsg-sulit-tembus-level-5000-pada-akhir-2015

Agustia, Y. P., Suryani, E., 2018. Pengaruh ukuran perusahaan, umur perusahaan, leverage, dan profitabilitas terhadap manajemen laba pada perusahaan pertambangan yang terdaftar di bursa indonesia periode 2014-2016. Jurnal ASET (Akuntansi Riset) 10 (1), 63-74.

Allen, C. C., Shen, J., Rhee, S. G., 2017. Fundamental analysis and stock returns in international equity markets. aut 21.

URL: https://acfr.aut.ac.nz/__data/assets/pdf_file/ 0006/105459/89145-20170803-Fundamental-analysis-and \ -stock-returns-in-international-equity-markets.pdf

Arista, D., Astohar, 2012. Analisis faktor-faktor yang mempengaruhi return saham pada perusahaan manufaktur yang go public di bei periode tahun 20052009. Jurnal Ilmu Manajemen dan Akuntansi Terapan (JIMAT). 3 (1), 1-15.

Bintara, R., Tanjung, P. R. S., April 2019. Analysis of fundamental factors on stock return. International Journal of Academic Research in Accounting, Finance and Management Sciences 9 (2), 2019.

URL: http://dx.doi.org/10.6007/IJARAFMS/v9-i2/6029

DOI: $10.6007 /$ IJARAFMS/v9-i2/6029
Cnbcindonesia, 2018. Kinerja indeks lq45 tahun 2018 lebih parah dibandingkan ihsg.

URL: https://www.cnbcindonesia.com/market/ 20181230184957-\17-48481/kinerja-indeks-lq45-tahun-\ 2018-lebih-parah-dibandingkan-ihsg

Fahmi, I., 2015. Pengantar Teori Portofolio dan Analisis Investasi. Penerbit Alfabeta, Bandung.

Fredrick, O., Muiva, B. N., 2015. Fundamental analysis of stock returns of nonfinancial firms listed at the nairobi securities exchangeuniversal. Journal of Accounting and Finance 3 (3), 113-116.

DOI: $10.13189 /$ ujaf . 2015.030302

Gunadi, G. G., Kesuma, K. W., 2015. Pengaruh roa, der, eps terhadap return saham perusahaan food and beverage bei. E-Jurnal Manajemen 4 (6), 16361647

Jogiyanto, 2017. Teori Portofolio dan Analisis Investasi. BPFE, Yogyakarta.

Khotimah, K., Murtaqi, I., 2015. The fundamental analysis of indonesian stock return (case study: Listed public companies in sub-sector food and beverage for the period 2003-2012). Journal Of Business And Management 4 (1), 95104.

Margaretha, F., 2014. Dasar-dasar Manajemen Keuangan. Dian Rakyat, Jakarta.

Moeljadi, 2006. Manajemen Keuangan Pendekatan Kuantitatif dan Kualitatif. Vol. 1. Banyumedia Publishing, Malang.

Muhammad, S., Ali, G., 2018. The relationship between fundamental analysis and stock returns based on the panel data analysis; evidence from karachi stock exchange (kse). Research Journal of Finance and Accounting 9 (3), 84-96.

Ozturk, H., Karabulut, T., 2018. The relationship between earning-to-price, current ratio, profit margin and return. Accounting and Finance Research 7 (1), 109-115.

Prihantini, R., 2009. Analisis pengaruh inflasi, nilai tukar, roa, der, dan cr terhadap return saham pada industri real estate and property yang terdaftar di bursa efek indonesia periode2003-2006. Master's thesis, Program Pascasarjana Universitas Diponegoro, Semarang, theses.

S., S., 2013. Analisis Fundamental dan Teknikal untuk Profit Lebih Maksimal. PT Gramedia Pustaka Utama, Jakarta.

Saniman, 2007. Analisis pengaruh rasio aktivitas, rasio profitabilitas, dan rasio pasar, terhadap return saham syariah dalam kelompok jakarta islamic index (jii) tahun 2003-2005. Master's thesis, Program Pascasarjana Universitas Diponegoro, Semarang, theses.

Sujarweni, W., 2014. Metodologi Penelitian. PT Pustaka Baru, Yogyakarta.

Susanty, D. Dan Batian, E., 2018. Pengaruh kinerja keuangan dan ukuran perusahaan terhadap return saham perusahaan sektor pertambangan di bei periode 2010-2016. Jurnal Riset Akuntansi Tirtayasa 3 (1), 20-44.

Suselo, D., A., D., Khusniyah, N., 2015. Pengaruh variabel fundamental dan makro ekonomi terhadap harga saham pada perusahaan yang masuk dalam indeks lq45. Jurnal Aplikasi Manajemen 13 (1), 104-116.

Susilowati, Y., 2011. Reaksi signal rasio profitabilitas dan rasio solvabilitas terhadap return saham perusahaan. Jurnal Dinamika Keuangan dan Perbankan 3 (1), 17-37.

Venkates, C. K., Tyagi, M., Ganesh, L., 2012. Fundamental analysis and stock returns: An indian evidence. Global Advanced Research Journal of Economics, Accounting and Finance 1 (2), 33-39.

William, F., Gordon, J., Jeffery, V., 1999. Investasi. Vol. 2. Prenhallindo, Jakarta. 